\title{
O TEMPO ESTRUTURAL DA COMUNIDADE DE SANTA LUZIA DO MARUANUM, AMAPÁ: VIVÊNCIAS DE TEMPORALIDADES POSSÍVEIS
}

\author{
David Junior de Souza Silva ${ }^{1}$ \\ Danielle Balieiro dos Santos ${ }^{2}$
}

Resumo: O objetivo desta pesquisa é a compreensão de como o tempo social se estrutura em contextos/espaços/temporais cuja organização sociocultural e manifestações simbólicas se estruturam em valores etnicamente singulares - como é o caso da comunidade Santa Luzia do Maruanum. A justificativa é a evidência de estruturas reais e empíricas de tempos sociais que contestam as concepções universalizadoras presentes nas atuais teorizações eurocêntricas sobre o tempo. Outrossim, a pesquisa sobre o tempo social e seus usos e sentidos tem implicações sobre a compreensão de parte dos sentidos de felicidade e bem-viver comunitário. Epistemologicamente, o estudo aqui proposto funda-se na perspectiva da interculturalidade e da pós-colonialidade. A metodologia empregada foi a etnografia junto à comunidade. Como resultados identificamos que o tempo social comunitário é feito por um tempo de trabalho, um tempo familiar, um tempo religioso, e um tempo de lazer cotidiano e festivo extracotidiano. O tempo social comunitário é feito também desse 'tempo escolhido', da autodeterminação, da autonomia relativa para decisão sobre o cotidiano.

Palavras-chave: comunidades tradicionais; Amazônia; tempo social.

\section{THE STRUCTURAL TIME OF THE COMMUNITY OF SANTA LUZIA DO MARUANUM, AMAPÁ: EXPERIENCES OF POSSIBLE TEMPORALITIES}

\begin{abstract}
The objective of this research is to understand how social time is structured in contexts/spaces/temporals whose socio-cultural organization and symbolic manifestations fester into ethnically singular values - as is the case of the Santa Luzia do Maruanum community. The justification is the evidence of real and empirical structures of social times that contest the universalizing conceptions present in the current Eurocentric theorizations about time. Furthermore, the research on social time and its uses and senses has implications on the understanding of part of the senses of happiness and community life. Epistemologically, the study proposed here is based on the perspective of interculturality and postcoloniality. The methodology employed was ethnography with the community. As a result, we identified that community social time is made up of time for work, family time, religious time, and extra-daily leisure and festive time. Community social time is also made up of this 'chosen time', of this selfdetermination, of this relative autonomy to decide about daily life.
\end{abstract}

\footnotetext{
${ }^{1}$ Professor Adjunto da Universidade Federal do Amapá (UNIFAP). Professor Permanente no Mestrado Profissional em Ensino de História da UNIFAP. Editor-Gerente da Revista PRACS - Revista de Ciências Sociais da Unifap, desde 2019. Pós-Doutorando no Programa de Pós-Graduação em História (Mestrado Acadêmico) da Universidade Federal do Amapá - PPGH/UNIFAP. Doutor em Geografia pelo Instituto de Estudos Socioambientais da Universidade Federal de Goiás (IESA/UFG). Coordenador do Núcleo de Estudos em Etnopolítica e Territorialidades da Amazônia - NETTA/UNIFAP. Membro da Rede de Pesquisa sobre Pedagogias Decoloniais na Amazônia. Integrante da Red Latinoamericana de Metodología de las Ciencias Sociales [RedMet].

${ }^{2}$ Pós-graduada em Estudos Culturais e Políticas Públicas, da Universidade Federal do Amapá. Graduada em bacharelado e licenciatura em Ciências Sociais, pela Universidade Federal do Amapá (2017).
} 
Keywords: traditional communities; Amazon; social time.

\section{EL TIEMPO ESTRUCTURAL DE LA COMUNIDAD DE SANTA LUZIA DO MARUANUM, AMAPÁ: EXPERIENCIAS DE TEMPORALIDADES POSIBLES}

Resumen: El objetivo de esta investigación es comprender cómo se estructura el tiempo social en contextos/espacios/temporales cuya organización sociocultural y manifestaciones simbólicas se encarnan en valores étnicamente singulares - como es el caso de la comunidad de Santa Luzia do Maruanum. La justificación es la evidencia de estructuras reales y empíricas de los tiempos sociales que impugnan las concepciones universalizantes presentes en las actuales teorizaciones eurocéntricas sobre el tiempo. Además, la investigación sobre el tiempo social y sus usos y sentidos tiene implicaciones en la comprensión de parte de los sentidos de la felicidad y la vida en comunidad. Epistemológicamente, el estudio que aquí se propone se basa en la perspectiva de la interculturalidad y la poscolonialidad. La metodología empleada fue la etnografía con la comunidad. Como resultado, identificamos que el tiempo social de la comunidad se compone de tiempo de trabajo, tiempo familiar, tiempo religioso y tiempo de ocio extracotidiano y festivo. El tiempo social comunitario también está hecho de este "tiempo elegido", de esta autodeterminación, de esta relativa autonomía para decidir sobre la vida cotidiana.

Palabras clave: comunidades tradicionales; Amazonas; tiempo social.

\section{Introdução}

Se aventurar a pensar o tempo humano à luz de suas impalpáveis significações, demanda muitos embaraços, o principal destes o fato de este ser uma realidade estruturante que condiciona o próprio esforço compreensivo.

Dessa forma, ao refletir o tempo por meio de suas expressões conhecidas trabalho, lazer e ócio - propôs-se, além de seus desdobramentos interpretativos contemporâneos - na História, nas Ciências Sociais, na Filosofia e na Psicologia -, uma ampliação para espaços/contextos socioculturalmente diferenciados contemporâneos: as comunidades tradicionais. As reflexões sobre tempos sociais são feitas em e para o mundo ocidental, ou mais precisamente, o mundo eurocêntrico. A proposta aqui é realizar a investigação sobre a estrutura do tempo social na comunidade Santa Luzia do Maruanum.

A sociologia dos tempos sociais, por exemplo, problematizam o lazer a partir da categoria tempo enquanto construção socialmente definida a partir da atividade do trabalho, reconhecida, implícita ou explicitamente, como estruturante universal e absoluta do tempo. O lazer como ocupação (DUMAZEDIER, 1979), atividades variadas (CAMARGO, 2008), vivenciado e pressuposto em um tempo disponível ou momento flexível entre as liberações das obrigações sociais, liberdade esta, considerando a configuração e os diversos impedimentos da sociedade contemporânea, que se refere ao 
maior discernimento do indivíduo em um tempo espontâneo para realizações pessoais (CAMARGO, 2008), somente se tornou conceitualmente e usualmente conhecido a partir da modernidade, esta enquanto marco dos direcionamentos reflexivos e epistemológicos que na contemporaneidade se tornaram fundamentais ${ }^{3}$.

No entanto, o lazer enquanto categoria argumentativa, que serviu para as fundamentações críticas ao comportamento consumista resultantes da cultura do capitalismo tardio, necessitou ser ressignificado, diante da necessidade de discutir as concepções que colocam as experiências etnicamente diferenciadas do tempo.

O fenômeno do ócio, por sua vez, considerado como experiência subjetiva, culturalmente enraizada, motivadora de satisfação existencial e de possibilidades para o desenvolvimento pessoal, conserva suas significações clássicas nas mesmas proposições de liberdade, discernimento de escolhas e felicidade — sentimentos que residem no sujeito de forma anterior à sua relação com o tempo e o espaço. No entanto, a partir da modernidade, a concepção de tempo assumiu outro estatuto, sobretudo quando a atividade do trabalho passa a organizar a dinâmica social e temporal da sociedade, deslocando a vivência possível do ócio como realização da subjetividade e da existência. A imposição moderna da ética do trabalho como absoluta distanciam os sujeitos sociais coletivos e individuais da realização de si.

O problema de pesquisa que pretendemos resolver aqui é o da compreensão de como o tempo social se apresenta em contextos/espaços/temporais cuja organização sociocultural e manifestações simbólicas se esturuturam em valores etnicamente singulares - como é o caso das comunidades tradicionais da Amazônia.

A justificativa é a evidência de esturuturas reais e empíricas de tempos sociais que contestam as concepções universalizadoras presentes nas atuais teorizações sobre o tempo. Sob esse ponto de vista, os sentidos de interculturalidade, como atitude que permite a consciência e diálogo entre as diferentes realidades culturais (CANDAU, 2006) se articulam com as reflexões que aproximam os sujeitos contemporâneos ${ }^{4}$ em suas performances de representações identitárias, especialmente as perspectivas pós-coloniais, como em Costa (2006). Tal conversa intercultural, no diálogo com outros sujeitos e modos de ser, saber, desafiam assim, a reposicionar os conhecimentos, as certezas

\footnotetext{
${ }^{3}$ Vale ressaltar que as bases do pensamento da modernidade na contemporaneidade, por meio de estudos, revisões e projetos pós-coloniais vêm sendo problematizada, reivindicada (BALLESTRIN, 2013), por meio de uma contestação do conhecimento, sob tentativas de releituras e diálogos com base nas próprias identidades, culturas e outros saberes alternativos, para além do conhecimento único.

${ }^{4}$ Sujeitos de identidades descentradas e possíveis de representação diante dos diálogos culturais de uma pós- modernidade, conforme Hall (1998).
} 
acomodadas (WEISSMANN, 2018) diante da permissão de discussão entre as diversas racionalidades parte da vida prática de pessoas (SANTOS, 2007) habilitando assim, dentro dos horizontes visíveis às próprias experiências de vida, a reivindicação de (re) leituras possíveis.

Dessa forma, trazer o tempo vivido das comunidades tradicionais à pauta dos estudos sobre tempos sociais desafia os instrumentais heurísticos hoje disponíveis, ao considerar as especificidades que configuram os universos simbólicos de diferentes percepções e vivências espaço/temporais. O ponto de partida da pesquisa, sua justificativa e seus objetivos são as significações próprias do tempo social para a comunidade, considerando sua dimensão cultural e sua história própria.

Isto é o que justifica a usabilidade do enunciado "vivências de temporalidades". Supõe-se por este enunciado encontrar caminho metodológico-empírico para as concepções de tempo comunitário, bem como suas relações com a dimensão cultural (BOAS, 2010, GEERTZ, 1978) e com a dimensão identitária, e suas características transformações e ajustes aceitos ou renunciados (POUTIGNAT; STREIFF- FERNART, 1998).

Admite-se assim, as complexidades dos percursos investigativos, tanto com relação ao ócio e suas projeções de experiência subjetiva, quanto as similaridades ao lazer, o qual recobra avistar ou compreender uma possibilidade temporal demarcatória para as realizações dessas experiências enobrecedoras, como também pelo deslocamento direcionado ao contexto da comunidade, estas norteadas pelas atribuições de comunidades tradicionais seus modos particulares de interação, suas cosmologias e saberes (SILVA, 2015).

O tempo social da comunidade é assim compreendido em abordagem etnográfica e perspectiva intercultural, e mediado por conceitos consolidados das teorias sobre os tempos sociais ainda que ocidentais: tempo estrutural (PRITCHARD, 1978), trabalho, lazer e ócio. A aplicabilidade destes conceitos à realidade singular de uma comunidade tradicional somente é possível porque mediada criticamente pelas reflexões pós-coloniais e decoloniais (MIGNOLO, 2003), por meio da qual se desloca o tempo social moderno de seu lugar absoluto colocado pelo eurocentrismo.

A perspectiva decolonial, aplicada ao tema desta pesquisa, ao contestar a colonização do tempo, abre espaço novo e livre para que o tempo se realize como expressão da subjetividade e criação cultural - expressão esta nominada pelo conceito filosófico de ócio. A construção desta problemática de pesquisa permitiu endereçamentos 
à comunidade tradicional de Santa Luzia do Maruanum, como forma de compreender primeiramente, quais as concepções de lazer existente entre os moradores da comunidade, as possibilidades e expressões de lazer disponíveis nesta comunidade tradicional, e posteriormente conseguir refletir a relação entre 'ócio' e o tempo social na comunidade.

Assim, os objetivos se concentram em compreender o ócio diante das expressões de lazer da Comunidade de Santa Luzia do Maruanum, com base nas significações subjetivas designadas à categoria filosófica de ócio e considerando a realidade e/ou diversidades cognitivas dimensionadas nas diferentes práticas e vivências culturais.

Como metodologia para esta pesquisa, optou-se pela utilização de uma abordagem etnográfica que permite observações e descrições acerca das características específicas da comunidade. Quanto aos procedimentos metodológicos foram realizadas pesquisas do tipo bibliográfica, documental e pesquisa de campo com visitação exploratória e excursões observacionais com os moradores residentes na comunidade quilombola de Santa Luzia do Maruanum, com realizações de coletas de dados, de entrevistas semiestruturadas orientadas previamente por questões chaves aos moradores residentes da comunidade.

Dessa forma, a primeira seção inicia com explicitações de alguns pontos importantes para o entendimento da escolha dos termos que implicaram no processo de adequação aos direcionamentos das investigações e aos procedimentos metodológicos da pesquisa, como o delineamento do lócus, a opção pelo método e o tipo de abordagem adotada para o estudo, bem como as técnicas e ferramentas utilizadas no levantamento de dados.

A seção seguinte apresenta uma análise quanto às informações colhidas a partir das entrevistas realizadas com os moradores da comunidade e narra e relaciona as perspectivas subjetivas dos moradores com as concepções apresentadas no arcabouço teórico. Como forma de cumprir os preceitos éticos requeridos para pesquisas com Seres Humanos, o estudo foi cadastrado na Plataforma Brasil, avaliado e aprovada pelo Comitê de Ética da Universidade Federal do Amapá, e autorizado pelo parecer nº 3.308.257.

\section{Metodologia}

Por se tratar de estudo que empreende a interpretação e compreensão das complexidades culturais (GEERTZ, 1978), optou-se pela utilização de uma abordagem etnográfica como processo metodológico para o alcance dos objetivos propostos. Vieira 
(2010, p. 93) explica que este tipo de abordagem compreende as investigações sensibilizadas e relacionadas ao estudo dos fenômenos humanos, tendo por principais características:

- $\quad$ o comportamento das pessoas é estudado no seu contexto habitual e não em condições artificiais criadas pelo investigador;

- os dados são recolhidos através de fontes diversas, sendo a observação e a conversação informal as mais importantes;

- a recolha de dados não é estruturada, no sentido em que não decorre da execução de um plano detalhado e anterior ao seu início, nem são preestabelecidas as categorias que serão posteriormente usadas para interpretar o comportamento das pessoas (o que não significa que a investigação não seja sistemática, mas apenas que os dados são recolhidos em bruto, segundo um critério tão inclusivo quanto possível);

- $\quad$ o foco do estudo é um grupo não muito grande de pessoas, mas, na investigação de uma história de vida, o foco pode ser uma única pessoa;

- a análise dos dados envolve interpretação de significado e de função de ações humanas e assume uma forma descritiva e interpretativa, tendo a (pouca) quantificação e análise estatística incluída, um papel meramente acessório (VIEIRA, 2010, p. 93).

Assim sendo, a etnografia consiste em um método de estudos e de observações voltado, sobretudo, para a análise de grupos sociais e que pode se utilizar de levantamentos de dados e observações acerca das características gerais e especificas do grupo - ou seja, um método que converge com o objetivo proposto.

Corroborando com as inferências de Triviño (2009), ao abordar a etnografia como forma específica de pesquisa qualitativa e em reconhecimento as suas implicações metodológicas, para as análises das características gerais, elege-se assim, as estratégias gerais, cujas investigações, compartilhamentos e participações ativas se direcionam às complexas realidades culturais interessadas.

\section{Procedimentos Metodológicos}

Quanto aos procedimentos metodológicos, foram realizadas pesquisas do tipo bibliográfica, documental e em campo campo com visitas à comunidade e interação com os moradores. Estes procedimentos subsidiaram uns aos outros durante todo o processo de pesquisa (figura 01 ). 
Figura 1 - Relação entre os procedimentos metodológicos adotados.

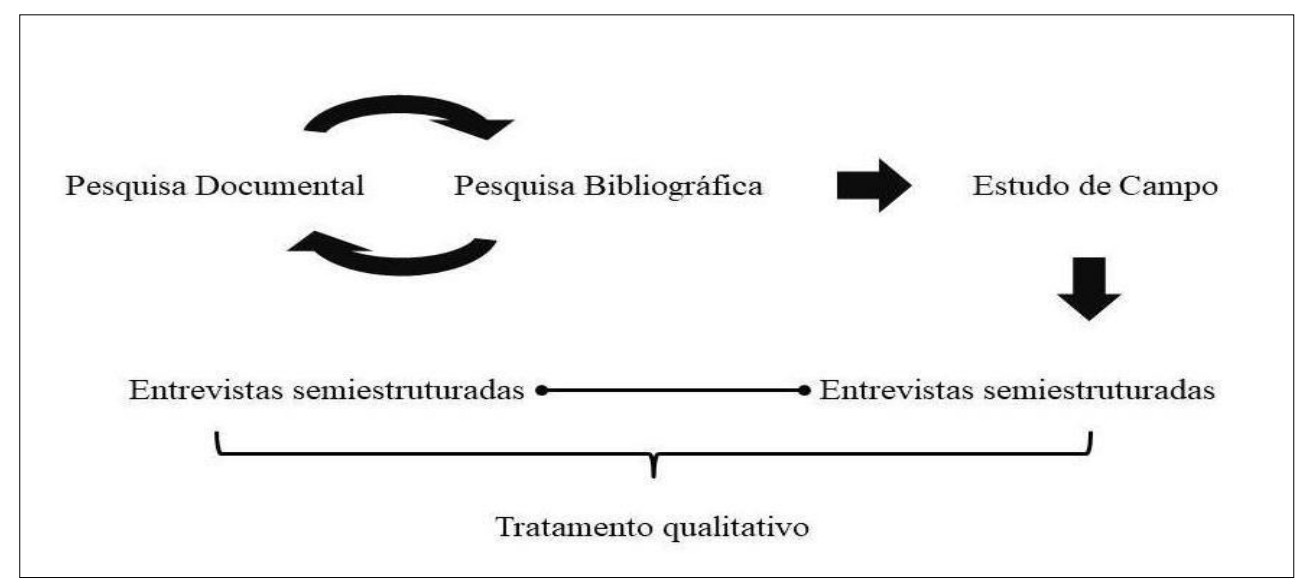

Fonte: Elaborado pela autora (2018).

A realização das pesquisas do tipo bibliográfica e documental teve por objetivo tanto possibilitar um conhecimento mais profundo sobre a região estudada, quanto dialogar com as interpretações e conceituações de produções nacionais, encontradas principalmente no Laboratório de estudos sobre o ócio, trabalho e tempo-livre - Otium, localizado em Fortaleza/CE. Como forma de subsidiar relativas dificuldades interpretativas e de acesso dada as demais produções disponibilizadas em outras línguas e países, também foram consideradas os estudos reunidos e produzidos pela Asociación Iberoamericana de Estudos de ócio, composta por Espanha, Portugal, e America Latina (MARTINS, 2017).

Além destes procedimentos, também foram realizadas coletas de dados a partir de entrevistas semiestruturadas com moradores da comunidade quilombola de Santa Luzia do Maruanum, localizada no município de Macapá, Amapá. As entrevistas semiestruturadas foram orientadas por questões-chaves previamente selecionadas, realizadas com moradores residentes na comunidade pesquisada, dentre os quais, aqueles que possuíam 18 (dezoito) anos de idade completos ou mais, no momento das entrevistas.

Dado ao fato de se tratar de uma pesquisa que fez uso do método etnográfico e ao fato de se buscar alcançar os objetivos propostos a partir de observações e descrições das particularidades coletivas e/ou individuais, optou-se pela realização de tratamento e análise dos dados a partir de um enfoque qualitativo.

O enfoque qualitativo, descrito por Freitas e Muniz (2008) como uma análise de conteúdos de percepções, opiniões e interpretações, ficou a cargo da consideração das opiniões expressas pelos moradores da Comunidade de Santa Luzia do Maruanum. Assim, para coleta das informações foram utilizadas como técnicas de pesquisa um 
profundo levantamento bibliográfico, que acompanhou todas as fases da pesquisa, e a realização de entrevistas desses moradores.

$\mathrm{O}$ arcabouço teórico que constituiu a pesquisa bibliográfica pautou-se em levantamento de estudos que abordam o 'ócio e seus conceitos ao longo da história'; 'o ócio na qualidade articulada as categorias dos tempos sociais, como o tempo livre, lazer e trabalho' e 'aproximações do lazer e ócio pela ideia de experiência subjetiva'; além 'da representatividade do lazer e ócio para as dimensões da comunidade estudada'. Portanto, a fundamentação teórica sobre lazer e ócio, encontrou-se embasada nas reflexões de autores como Aquino e Martins (2007); Rhoden (2009); Cabeza (2016) e outros que desenvolvem estudos em centros específicos dedicados à temática do ócio e suas dimensões na contemporaneidade, cujos trabalhos, artigos e discussões puderam ser encontrados em sites e plataformas de divulgação científica.

Para as reflexões teóricas que abordam comunidades tradicionais e suas características estudadas amparou-se, ainda, nas reflexões de autores como Diegues (1996), Diegues et al. (2000); Almeida (2008); Pereira e Diegues (2010); Brandão e Borges (2014) e entre outros. Quanto às entrevistas realizadas, foi considerada para o estudo a visão de mundo dos moradores da comunidade, selecionados de forma aleatória segundo o aspecto de disposição pessoal no momento de intervenção para participação da pesquisa.

A preferência pela comunidade deveu-se às importantes ampliações dos olhares reflexivos sob as outras possibilidades organizacionais de tempo e espaço na contemporaneidade, tais como relacionadas às peculiaridades socioculturais da comunidade, sua visão de mundo, suas rotinas, suas vivências temporais e seus ethos. Um cenário geográfico (cognitivo/subjetivo) em diálogo com as concepções de experiências de ócio, intermediadas pelas conexões experimentais do que se entende por lazer.

O interesse que se direcionou ao lócus da pesquisa também intencionou uma forma de sugerir reflexões que possam contribuir às possíveis aberturas de outras interpretações atentas das diversidades socioculturais, e /ou narrativas de outros espaços geográficos e seus saberes, coerente com as perspectivas pós-coloniais em geral (SANTOS; MENESES, 2010), e no que sugere endereçamentos às possíveis traduções semânticas, no que se referem ao ócio e suas projeções significativas à contemporaneidade.

As ciências físicas contribuíram para as concepções plausíveis diante de seu 
aspecto intangível às compreensões, impelidas pelas necessidades do desenvolvimento de métodos organizadores, adaptados às atividades humanas. Logo, o desenvolvimento da cronologia se tornou determinante para a condução do ritmo habitual da sociedade (Elias, 1998).

Para a filosofia, o tempo representava uma questão a qual se dedicavam pensadores como Aristóteles, Agostinho e Heidegger, que compreendiam o tempo como algo que se relacionava com a sensibilidade humana pela percepção que cada um possui da sucessão temporal entre o movimento anterior e posterior (ou, na concepção de Kant, pelas experiências junto ao espaço social) (REIS, 1996).

Nos estudos da sociologia, o tempo constitui uma construção social que compreende a criação simbólica que organiza as diversas sociedades. Consoante a este pensamento, Elias (1998) indica que o tempo surgiu da necessidade dos homens em suas interações sociais circunscritas pelo desenvolvimento espacial e pelas mudanças quanto ao ritmo das dinâmicas da sociedade de inventar um mecanismo que intermediasse as relações espaciais, que pudesse servir de modelo e ser padronizado, considerando as características organizativas de cada sociedade.

Para Silva (2010), apoiado em Elias, o tempo compreendido a partir da ideia de experiência permite ampliar os limites das suposições especulativas sobre o mesmo, assim, o tempo como social possui uma complexa significação simbólica, ordenativa, porém não universalista, pois se constrói sobre formas diversas e em diferentes tempo e espaço.

Os objetivos e aspectos relativos à pesquisa foram apresentados oralmente aos participantes e formalizados através da assinatura do Termo de Consentimento (modelo utilizado em apêndice), o qual prevê o anonimato dos indivíduos investigados e garante os aspectos ético-científicos consonantes às diretrizes e normas que regulamentam os estudos envolvendo seres humanos, dispostos na Resolução CNS 196/96. Convém mencionar que, no decorrer da seleção dos mesmos, necessitou-se de auxílio de um representante direto da comunidade, como forma de subsidiar as intervenções das entrevistas, caso fosse necessário, conforme acordado ao comitê de ética.

Como instrumento de pesquisa, optou-se pelo uso de roteiro pré-elaborado e semiestruturado para realização das entrevistas, contendo questões abertas relativas ao tema proposto e com abordagem de pontos considerados pertinentes para o delineamento e finalidade do estudo. As questões iniciais pautaram-se na identificação dos sujeitos da pesquisa, revelando sexo, idade e 'ocupação' (atividade relativa à trabalho); em 
sequência, as questões introdutórias relativas aos aspectos organizacionais da rotina, relevando as peculiaridades de suas utilizações 'temporais', as vivências e os lugares utilizados para diversão, aproximando assim das expressões de lazer e, por fim, abordaram-se as concepções individuais sobre o 'lazer' como tempo socialmente construído ou consentido como um tempo ou atividade necessária. Além disso, todo esse processo investigativo procurou avistar reflexões sobre o tempo social.

As entrevistas foram realizadas entre os dias trinta e trinta e um de maio do ano de dois mil e dezenove, obedecendo ao cronograma de disponibilidade previamente acordado com os participantes, variando entre o período da manhã e/ou da tarde, dentro do próprio ambiente da comunidade dos entrevistados. A maioria destas autorizações foi realizada na própria residência dos mesmos.

Para o processo de tratamento, os dados orais obtidos foram transcritos, organizados e analisados através do programa Office Word 2010, no qual os participantes entrevistados foram codificados por meio de representação gráfica da seguinte forma: para se referir à pesquisadora, utilizou-se a letra ' $\mathrm{P}$ '. Quanto aos entrevistados, os mesmos foram codificados sequencialmente segundo a ordem das entrevistas realizadas, utilizando a letra 'E' (E1, E2, E3, E4, E5, E6, E7, E8, E9 e E10) para designar os mesmos.

\section{Do Lócus De Pesquisa}

A comunidade de Santa Luzia do Maruanum ${ }^{5}$, segundo Iaparrá e Lomba (2014), fica localizada aproximadamente a $60 \mathrm{~km}$ ao sudeste da capital de Macapá e segundo o levantamento populacional de 2013 efetuado pela própria associação dos moradores, a comunidade referida possui 86 famílias em seu território. O acesso à comunidade de Santa Luzia do distrito de Maruanum, pode ser feito via terrestre, pela BR 210, ou por via fluvial (COSTA; CUSTÓDIO, 2017). O rio Maruanum afluente do Rio Matapi, conforme Silvani (2012) demarcam os referências entre as demais comunidades, além de influenciar em toda dinâmica de vida da população local, cuja dependência dos recursos naturais serviram para consolidar, por meio do conhecimento climático amazônico, as estratégias de sobrevivência. Autodefinidas como remanescentes quilombolas, a comunidade de Santa Luzia do Maruanum, dentre as demais comunidades existentes no distrito de Maruanum, foi a única a solicitar ao INCRA (Instituto Nacional de

\footnotetext{
${ }^{5}$ Apesar de não titulada, Santa Luzia do Maruanum I é reconhecida como área quilombola com certidão emitida pela Fundação Cultural Palmares, em 04 de outubro de 2011, e processo de reconhecimento pelo INCRA iniciado no ano de 2012, através do processo n. 54350.000221/2012-89 (CPISP, 2019).
} 
Colonização e Reforma Agrária) a abertura ${ }^{4}$ de regularização fundiária, um processo longo que objetiva garantir a confiança jurídica que os legitimaram como proprietários da terra, tendo em vista a caracterização de remanescentes de quilombos (IAPARRÁ; LOMBA, 2014).

Mapa 1: Localização do Distrito do Maruanum

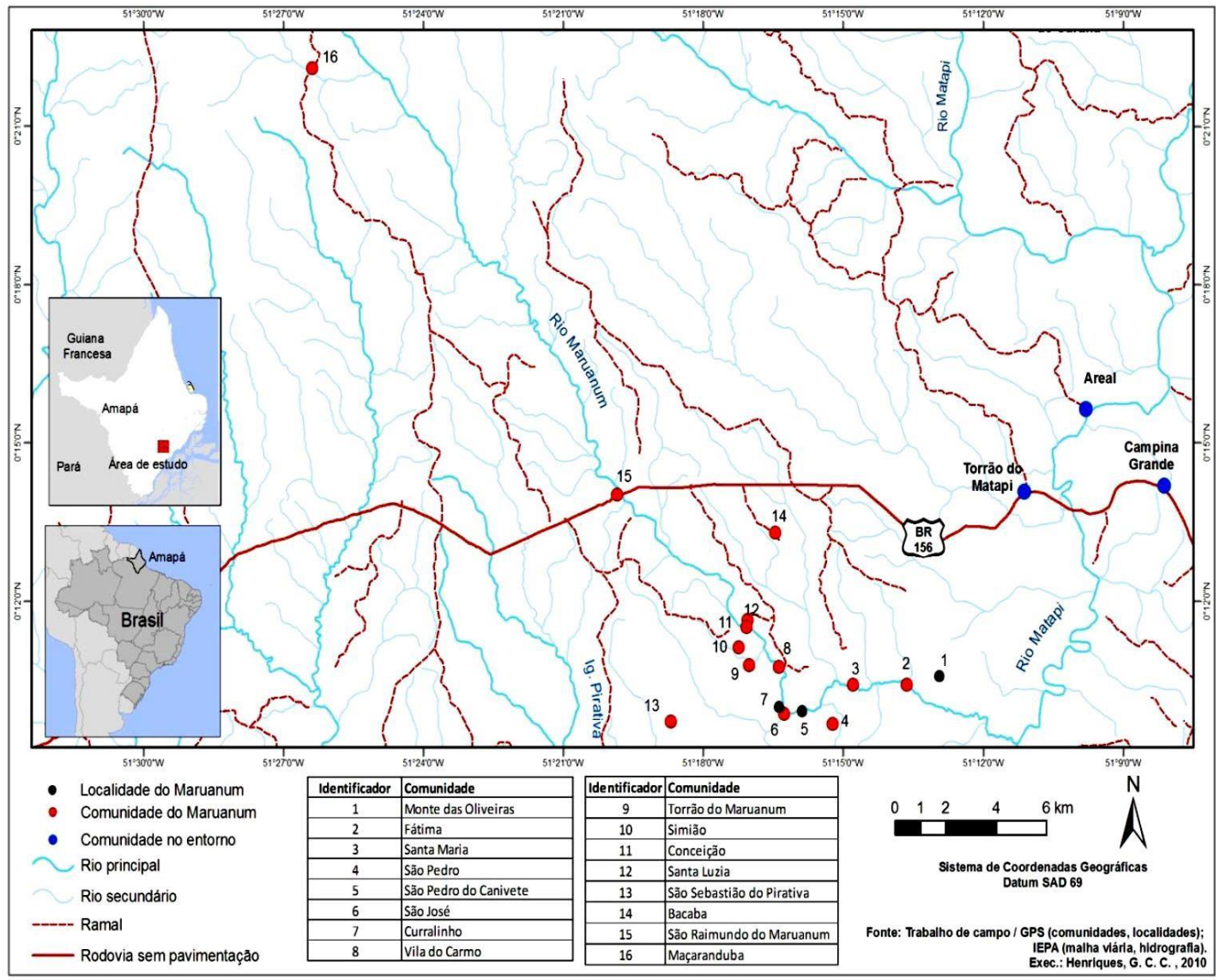

Fonte: Henriques (2011).

Conforme Rocha (2009) diante dos impasses sobre as caracterizações das especificidades dos quilombos enquanto remanescentes, a garantia do território como lugar de experiências específicas dos grupos torna possível a recuperação que estabelece significado de cada lugar, reforçando as características identitárias compreendidas e nos termos constitucionais, como pretextos contra-hegemônicos diante dos enfrentamentos políticos, econômicos e culturais persistentes.

A expressão remanescente quilombola, conforme Almeida (2008), foi delineada em contextos contemporâneos, cujas mobilizações no que concerne ao autoreconhecimento de uma política identitária ainda incutem em revisões no âmbito teórico ao jurídico. Esse processo de afirmação étnica, ainda conforme o autor, não sobreveio a 
partir dos parâmetros da Constituição Federal de 1988, mas resultou nos mesmos. A maior visibilidade desses movimentos sociais ${ }^{6}$ permitiu resultados expoentes em meio aos diversos conflitos territoriais específicos. Como territorialidades específicas Almeida (2008), procura diferir de terra ou território, fazendo alusão à forma específica de organização, que pode ser contínua, o que reforça assim a expressão da identidade sobre o atributo coletividade.

Como 'territórios de liberdade' conforme Iaparrá e Lomba (2014), os quilombos, em parâmetros modernos, configuram comunidades que desenvolvem suas práticas rotineiras de maneira diferenciada, cuja relação com a 'terra' se mostra um fator principal para a reprodução das práticas produtivas que lhe garantem a autossuficiência. Assim, a partir das ampliações definidoras e contempladoras atuais, o território compõe uma categoria basilar para as definições de sociedades tradicionais (DIEGUES; PEREIRA, 2010).

O termo quilombo, de acordo com Arruti (1997), traduz as similaridades descritivas inferidas, mas sem perder de vista as particularidades e suas dinâmicas de organização, nas mesmas dimensões que tangem as características (políticas) em torno dos 'povos ou comunidades tradicionais', reflexões atributivas estas, que sob a expressão de sociedades tradicionais permitem tais abrangências.

A utilização da expressão 'sociedades tradicionais' faz referência aos:

[...] grupos humanos culturalmente diferenciados que historicamente reproduzem seu modo de vida, de forma mais ou menos isolada, com base em modos de cooperação social e forma especificas de relação com a natureza, caracterizados tradicionalmente pelo manejo sustentado do meio ambiente. Essa noção se refere tanto a povos indígenas quanto a segmentos da população nacional que desenvolvem modos particulares de existência, adaptados a nichos ecológicos específicos (DIEGUES; ARRUDA et al., 2000, p. 22).

Ampliações que se coadunam, diante das necessidades que insurgem na contemporaneidade, para contemplar as diversas comunidades, grupos, famílias existentes e cujo território compõe a categoria basilar para a identidade coletiva (DIEGUES; ARRUDA et al., 2000).

Compreende-se o tradicional, não apenas como referente ao legado histórico que muitas vezes pode fazer alusões às conotações de estabilidade - mas como termo que remete à tradução de ações legitimadoras, o que reforçam o reclame ao lugar de

\footnotetext{
${ }^{6}$ Para Almeida (2008), a conotação de 'novos movimentos sociais' ultrapassa as estratégias de discursos, posicionam os sujeitos da ação, cujas identidades são autoafirmadas em reconhecimento de uma existência coletiva, 'politizando' não apenas as nomeações de sua vida cotidiana, mas seus modos seus modos de viver, suas práticas rotineiras e uso dos recursos naturais.
} 
pertencimento pelo vivido e pelo existir contínuo (BRANDÃO; BORGES, 2014). O que torna o espaço um atributo de produção identitária.

Não cabe aqui, adentrar nessas inferências terminológicas que se mostram necessárias para articular com as afirmações políticas desses grupos, o que alargaria as reflexões insurgentes. No entanto, sem desconsiderar as relevâncias dessas discussões, sob os processos de (res) semantização na contemporaneidade (LITTLE, 2004; FILHO, 2011); optou-se pela utilização da denominação de 'comunidades tradicionais' nesta pesquisa em decorrência de facilitar a localização da comunidade de Santa Luzia do Maruanum, delineado ao contexto espaço/temporal investigado.

Amparando-se nas contribuições de Brandão e Leal (2012), compreende-se assim, de maneira breve, comunidade como lugar social de escolha, de reunião e vivências, entre palavras e gestos, restituídas de sentido; e em Souza Silva (2020), como o compartilhar de um destino em comum, vinculado a um território.

Neste sentido, conforme Iaparrá e Lomba (2019) as práticas produtivas de Santa Luzia possuem as características de autonomia - mesmo sob uma influencia relativa da relação capitalista - cuja atividade econômica caracteriza-se como de subsistência, relacionada à produção agrícola, como a criação de animais. Seu contexto histórico se enreda por histórias que configuram a noção de memória coletiva ${ }^{7}$ e que revelam a influência do contato indígena (SILVANI, 2012).

Ainda se mantém, na comunidade de Santa Luzia do Maruanum, as práticas tradicionais de caráter religioso por meio da dança, do batuque, marabaixo, ladainhas, novenas e procissões, além da preservação da tradição da prática artesanal no que se refere a produção das louças feita de barro (IAPARRÁ; LOMBA, 2014).

\section{Santa Luzia do Maruanum: Expressões de Trabalho e Lazer}

O tempo estrutural é formado de diferentes elementos. Trabalho, lazer e ócio são alguns deles na sociedade da modernidade. Com base na complexidade interpretativa em reconhecer nas manifestações de lazer os vestígios daquilo que se entende por ócio, dada sua introdução em contextos espaço/temporais diferenciados daquele racionalizado pelos estudos contemporâneos, buscou-se nas aproximações de lazer condizentes com as

\footnotetext{
${ }^{7}$ Silvani (2012) contribui para as compreensões de memória coletiva a partir das impressões de Halbwachs (2004), indicando que a memória coletiva se traduz no âmbito do contexto social de origem, reconstruído continuamente, contornando a ativação da existência do grupo de referência histórica e simbólica.
} 
significações subjetivas de ócio, desenvolver as questões direcionadoras aos entrevistados, por meio de perguntas perceptivas que abordam as perspectivas intimistas de felicidade, de diversão e organização temporal, com vistas a considerar as peculiaridades das vivências e experiências locais. Dessa maneira, se fez necessário identificar o perfil dos entrevistados, como forma de convocar interpretações por meio de indícios compreensivos à luz de características próprias da organização local, cultura e suas práticas e percepções de mundo, todas estas em concordância com as questões da pesquisa.

Dentre os 10 entrevistados abordados, maiores de 18 dezoito anos de acordo com os requisitos éticos da pesquisa, a idade variou entre 20 a 86 anos de idade, 09 alfabetizados e 01 analfabeto, sendo este último previamente acordado por meio da intermediação de um representante direto da comunidade. E ainda, dentre os entrevistados, foram acolhidos quatro homens e seis mulheres, o que reforçou a presença marcante do sexo feminino.

Conforme estudos de Ferreira (2016) as mulheres, na ocupação geral de Maruanum, devem ser reconhecidas como personalidades importantes na construção identitária das comunidades quilombolas, pois suas presenças, além de garantir e manter as técnicas e saberes da produção da cerâmica, práticas estas que representam uma das expressões da cultura local, contornam um protagonismo de atuação e manutenção da história e memórias locais.

Ainda que a temática não caiba em aprofundamentos nas investigações da pesquisa, os percursos iniciais de descrição do perfil dos entrevistados para o desenvolvimento das discussões, esboçam questionamentos sobre a atuação feminina na construção da identidade e cultura da comunidade, aproximando com as discussões na atualidade que conforme Gonçalves (2006) contribuem para problematizar os discursos historiográficos invisibilizando-as sob os padrões patriarcais, dimensões reflexivas estas, que se mostraram interessantes para oportunas investigações.

Sobre os pressupostos de tempos sociais, as quais o lazer, o trabalho e o ócio se articulam na contemporaneidade (MACIEL; SARAIVA; MARTINS, 2018) e com base nas investigações no contexto da comunidade de Santa Luzia do Maruanum, para perceber os delineamentos de um tempo social determinante, um tempo que permite pensar as bases sustentadoras dos processos sociais. Suas vivências temporais, conforme Oliva-Augusto (2002), expressam a sobrevivência das relações de sociabilidade e atos que lhe atribuem valor simbólico, vivências que podem estar atreladas a atividades 
específicas, cada qual com sua influencia no ritmo da sociedade.

Figura 2 - Santa Luzia do Maruanum: produção de farinha

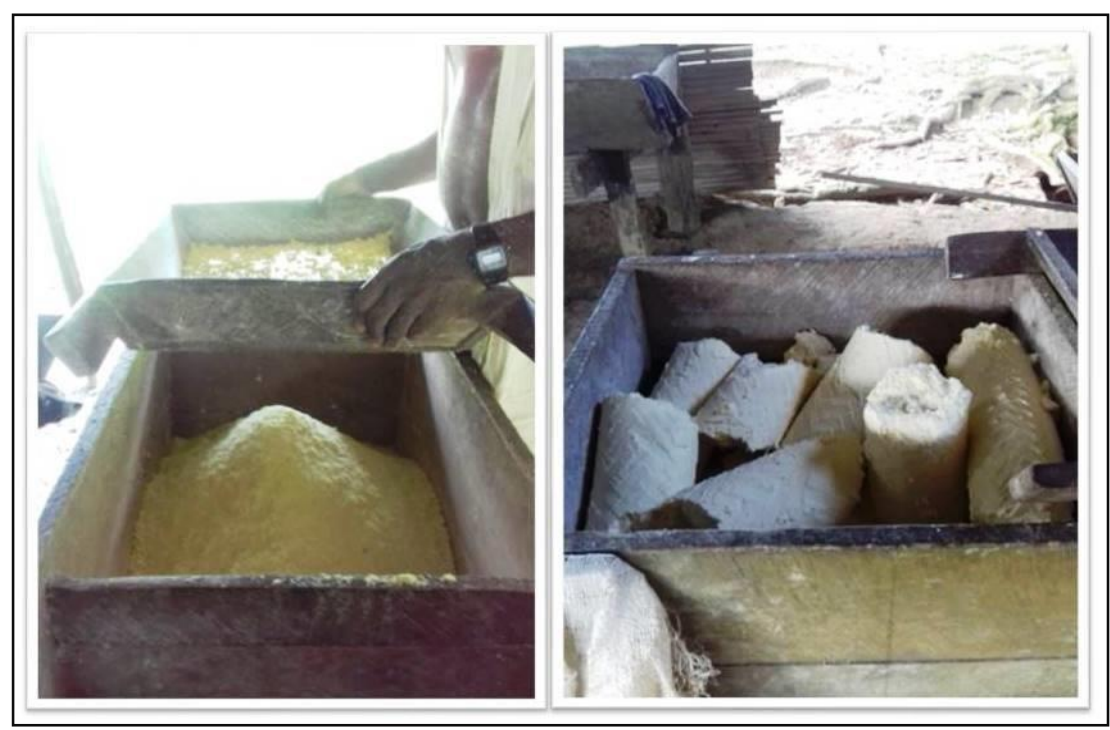

Fonte: Pesquisa de campo (2019).

A indagação inicial sobre qual trabalho (como ocupação) cada morador realiza permitiu adentrar articulações temporais justapostas entre e lazer e trabalho, cujas demarcações se definem mutuamente. Com relação à 'ocupação' ou 'trabalho' realizado, ainda sob o âmbito da identificação do perfil dos sujeitos entrevistados, a maioria se descreveu como agricultor(a), sendo que tais 'práticas de trabalho' puderam ser relacionadas com a produção da farinha, a pesca, o plantio, a roça, a criação de animais e a fabricação de louças de barro.

Figura 3 - Santa Luzia do Maruanum: plantações domésticas

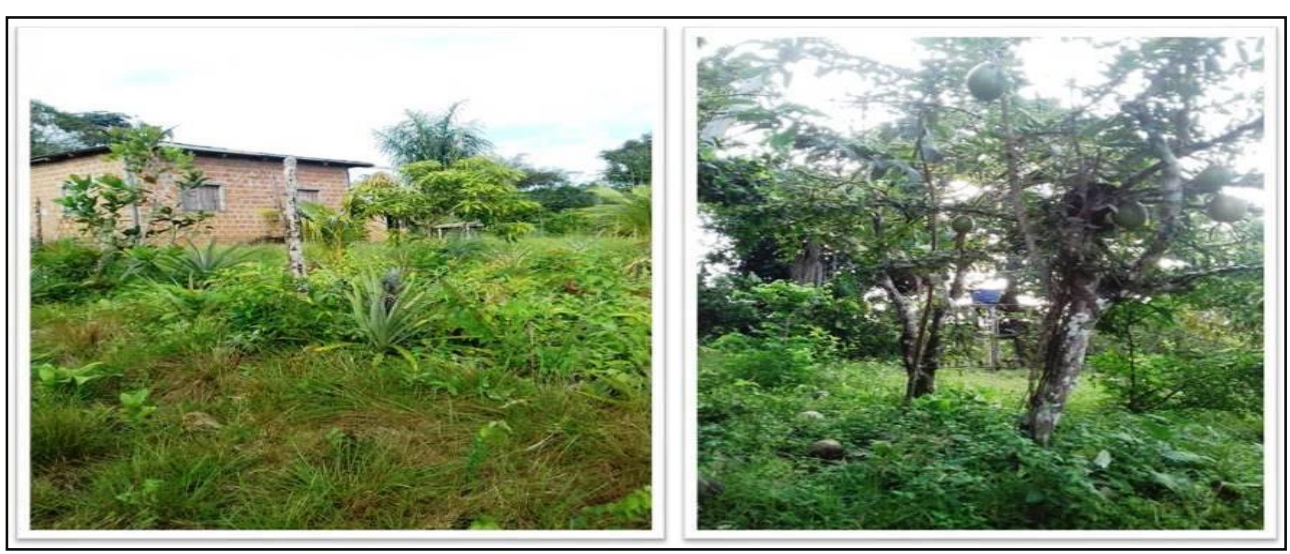

Fonte: Pesquisa de campo (2019). 
Conforme as considerações de Diegues et al (2001), uma das descrições acrescidas às denominadas comunidades tradicionais se referem como sociedades que ultrapassam os sentidos de simples ocupação do território, pois abrangem práticas de transformação da natureza, as quais implicam um longo processo de apreensão e perpetuação dos saberes e por meio de um mínimo de recursos tecnológicos, tornam o espaço natural uma possibilidade de vivência social, produtiva e equilibrada.

Acrescidas às considerações de Packer (2012), povos e comunidades tradicionais, dentro das suas praticas e técnicas de conhecimento, sabedoria e ancestralidade no trato com a terra, vêm mantendo e recriando tais comportamentos de utilização da biodiversidade, por meio de um conhecimento próprio de usos e conservação da natureza.

A forma e característica do trabalho produtivo não possuem atribuições de relações capitalistas (IAPARRÁ; LOMBA, 2014), ainda que a aproximação do contexto urbano capitalista contornem aproximações com este, no que concernem suas similaridades com uma economia de mercado capitalista, a exemplo da venda da louça ou da farinha para a capital. A 'atividade de trabalho' nessa comunidade, no entanto, possui a preponderância de atividades de características de subsistência e de produção para o comércio.

Nas reflexões estruturais materialistas de Mészaros (2002), o metabolismo social do capital, que se adapta no capitalismo, delineou as relações humanas de trabalho em torno das relações de produção, cujo valor de troca se sobrepõe ao de uso. Diferentemente dessa reprodução racionalizante da produção, conforme Monlevade e Caetano (2017) insurgem e coexistem outras formas alternativas de sobrevivência na contemporaneidade, a exemplo da produção associada, caracterizando uma forma de trabalho coletiva, consciente, democrática e pautado na distribuição igualitária da produção. Tais atribuições organizativas de produção, com base em Diegues et al (2000), se assimilam com as práticas tradicionais das comunidades tradicionais, no qual a acumulação de capital se apresenta de maneira reduzida, cujo manejo da terra e dos recursos expressa sua organização diferenciada.

Logo as características temporais que dimensionam a atividade do trabalho, como jornada de trabalho, rotinas trabalhistas e fim da produção, entendidas à luz de uma cronologia moderna capitalista, inicialmente, se apresentam, diferenciadas. O que torna relativo assim, a ideia de tempo fragmentado preenchido por um tempo disponível no que tange as concepções de lazer funcionalista (MARCELLINO, 1996) e dada as particularidades que contornam a 'temporalidade social' no contexto da comunidade de 
Santa Luzia do Maruanum.

No entanto, o lazer significado pelo aspecto subjetivo ou por experiências de ócio (MARCELLINO; PUKE, 2013) possibilitam repensar sua formatação por meio da dimensão da cultura, pois tais (re)atualizações articuladas ou (re)significadas se apresentam contundentes com as complexidades inerentes ao contexto da sociedade. Gomes (2014) indica que o lazer importado da ideia moderna, eurocêntrica de oposição ao trabalho, na contemporaneidade 'pós-epistêmica moderna/colonial', ao se manter limitado nessas compreensões, não consegue dialogar com as diversas e diferenciadas experiências sociais e socioculturais existentes.

Ao questionar sobre a utilização do tempo individual de cada sujeito entrevistado, buscou-se entender como a 'lógica cronológica', por assim dizer, se estabelece nesses contextos da comunidade, sob a intenção de assim poder avançar nas reflexões sobre a relação temporal acrescida ao lazer e as possibilidades de ócio nas discussões contemporâneas restituídas como vivências subjetivas e prazerosas.

Com base nas respostas, percebeu-se que o 'preenchimento do tempo' se relaciona com as atividades de subsistência e cultura desses moradores, expressas nas palavras de caçar, pescar, trabalhar na roça ou agricultura e preencher o tempo com práticas ancestrais de artesanato, como o 'trabalhar com o barro' — estas entendidas como vivências temporais características da própria cultura e suas práticas rotineiras auto-estabelecidas. Além dessas percepções de uso do tempo, acrescentaram-se aquelas com características condicionadas à família, como o cuidar da casa e aquelas que assumem sentidos de convivência social ou familiar. Exsite então como parte deste tempo estrutural um tempo familiar.

As atividades todavia não são o preenhimento do tempo. Elas são o próprio tempo. O sentido de fazê-las, as atividades em si e o estado de espírito com que se as vive, são o tempo comunitário.

Quadro 1 - Santa Luzia do Maruanum: uso do tempo

\begin{tabular}{l}
\hline P: como você utiliza seu tempo? \\
\hline E1: "Pescar, caçar e jogar bola". \\
E2: "Paro... Vou pra casa dos vizinhos, das filhas...". E3 "Trabalhando com roça, com \\
barro". \\
E4: "Agricultura... E de lá pra casa, né". \\
E6: "Além do trabalho, a organização da casa na semana, no final de semana... tomar banho \\
no rio, beber uma cervejinha, conversar, dançar e brincar".
\end{tabular}

Fonte: Elaborado pelos autores. 
De acordo com Rhoden (2009) as experiências de ócio ou liberdade temporal possuem essas conotações de liberdade percebida e autogeridas na qual, sob a dimensão temporal, refletem condições de liberdade de escolha. Para Aquino e Martins (2007) o tempo livre acrescido de práticas de lazer, deveria ser contornado como um tempo social sem dificuldades de compreensão para se realizar, ou seja, se referir a atividades autocondicionadas.

Além dessas práticas assumidas pela ideia de 'realização temporal', tais ocorrências podem ser configurar como momentos de escolha e de prazer, como o ato de 'cuidar das plantas', de 'brincar', 'jogar bola' (interpretado também como prática esportiva) - atividades de lazer, ou seja, em que a ludicidade impressa em suas significações sentido às experiências vividas.

Quando questionado sobre a possibilidade de um roteiro habitual, individual ou com vias ao coletivo, considerando a demarcação peculiar da rotina desses moradores, intencionou-se perceber qual a dinâmica que se estabelece para estes, tendo em vista a necessidade interpretativa para a construção da relação significativa que parte das compreensões do lazer para se refletir o ócio.

Com base nas respostas, percebeu-se que o ato de 'acordar cedo' ou de não se prender a uma demarcação imposta pela atividade de trabalho - como a prática da agricultura - condiz com a percepção demarcatória temporal dos moradores, no que confere as necessidades subjetivas e coordenadas por um 'tempo ecológico" (PRITCHARD, 1978), relacionado à dinâmica das atividades rurais e relacionado à rotina com cuidados pessoais, como hora auto-estabelecida para o repouso, dinamismo em que as relações sociais corporificam a cultura nas interações e representações com o espaço comunitário (DIEGUES, 1996).

Elias (1998) explica que a autorregulação, seja ela amparada por um tempo social ou natural, se mostram próprio da aprendizagem de toda espécie humana, suas comunicações por meio de símbolos sociais dessa maneira, também contornam tal regulação da realidade. No entanto ainda conforme o autor, nas sociedades por ele denominadas complexas, as restrições demarcatórias podem se apresentar com frequência variável, concomitante a uma autodisciplina e moderada repressão social.

O tempo de ocupação percebido pelo trabalho de professora de uma das moradoras da comunidade determina uma rotina cronológica cansativa, que pode diferenciar superficialmente dos demais. Assim, acredita-se que a rotina do trabalho nos 
modelos capitalistas, relativamente presentes na organização diária desta e de alguns moradores, transforma essas percepções de 'tempo natural' ou autorregulado para um tempo calculado, adequado às realizações de atividades impostas. $\mathrm{O}$ que pressupõe toda uma organização rotineira que se adapta ao ato cuidar da casa, da família, do lazer com relação ao trabalho, este ultimo, por vezes, extenuado no próprio ambiente do lar.

Experiências de lazer ou de ócio desprovidas de sentido subjetivo, consoante às sugestões capitalistas ou "utilitarista de tempo", dessa maneira, comprometem as mobilizações intencionais qualitativas (MARTINS, 2008). Esses fatores comprometedores, que impedem o usufruir de um tempo pessoal, foram percebidos com relação a rotina da entrevistada E6, pois, nas falas e no próprio processo de execução da atividade presenciada, o estresse, a preocupação em torno de findar o trabalho ou atividade tensionada relativa ao plano de aula se fez manifestar.

No entanto, dialogando com Diegues (1996) no que se refere às reflexões sobre as mudanças sociais, a presença, mais ou menos pressionante, de padrões de modo de culturas capitalistas, não significa a incorporação total capaz de transformar em curto prazo a longa representação de experiências passadas da cultura tradicional. Ao querer identificar os lugares ou práticas frequentadas no âmbito da comunidade em busca de lazer pelos entrevistados, sob a perspectiva da diversão, tencionou-se perceber a relação que se estabelecia entre as compreensões de lazer da comunidade e suas manifestações e práticas (de diversão), conforme uma cultura local e espaço/temporal.

Assim, com base nas respostas, a maioria procura 'se divertir' por meio de realizações e práticas dimensionadas ao contexto da comunidade, sendo estas delineadas pelos aspectos culturais, tais como as festas, o marabaixo, e as práticas relacionados à religião, além do convívio nos próprios espaços geográficos, no que concerne ao rio ou balneário, e ainda, por meio de práticas de sociabilidade comunitária expressas como o ato de ir à casa dos vizinhos.

Quadro 2 - Santa Luzia do Maruanum: lugares para se divertir

\section{P: Quais os lugares frequentados ou atividade realizável no âmbito da comunidade quando quer se divertir?}

E5: "Não, agora não, antes era o marabaixo... Ih, eu gosto de mais de marabaixo...". E6: "Só nosso balneário. Aqui na nossa vila só tem um".

E7: "Aqui na comunidade".

E8: "A igreja, a sede de santa Luzia... quando tem aí".

Fonte: Pesquisa de campo (2019). 
Buscou-se entender como as expressões de lazer se apresentam nesse contexto cuja vivência possui relação com a 'cultura local'. Isto implica questões sobre os sentidos que a comunidade atribui a lazer e ócio.

Assim, questionando o que os moradores compreendiam por lazer, tomei nota de que alguns entendiam o lazer como o cuidar de si, o ato de sair de casa e passear (mesmo que esta saída se referisse a ir à casa do vizinho e emprestar 'sal' como meio de conversar, como exemplificou a entrevistada E5), mas, sobretudo, percebeu que o lazer, na compreensão dos entrevistados, se relaciona como algo direcionado às possibilidades relativas ao contexto da comunidade, seja este ao contexto do espaço geográfico - como a ação de ir ao rio ou balneário — ou ainda entendido pela possível relação com as vivências culturais - como ir às festas locais e frequentar a igreja.

A alusão ao significado de diversão também foram atribuídos ao entendimento de lazer, como divertimento relacionado com a prática de jogos lúdicos: jogar bola, jogar dominó; e, ainda, o divertimento acompanhado pelo consumo de bebida, além de ser compreendido como momento possível aos finais de semana - o que indicaria a ideia de uma medição temporal. O entendimento de lazer também foi associado às significações de cuidado pessoal e de convivência com as pessoas da comunidade, revelando uma consciência que pode fazer relação com as interpretações de expressões de sociabilidade comunitária.

Figura 4 - Igreja de Santa Luzia do Maruanum

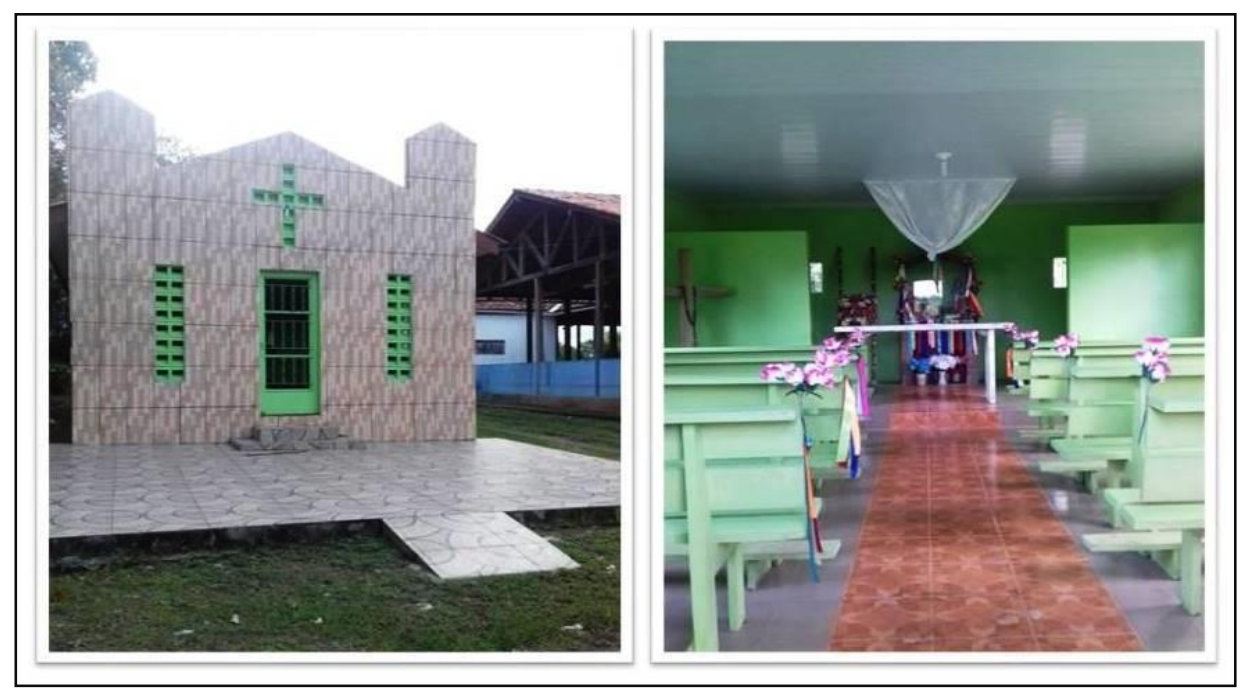

Fonte: Pesquisa de campo (2019). 
Conforme Hall (2007), as identidades são construídas por meio de sentidos e representações que garantem o sentido que correspondem ao espaço imaginado, o que confirmaria a ideia de territorialidade específica, a qual Almeida (2008) condensa como aspecto de identificação e atualização das interações sociais.

Com o objetivo de compreender as articulações entre práticas de lazer e a cultura local perguntamos sobre quais períodos do ano há atividades de lazer. Os períodos indicados nas respostas se relacionam com os eventos próprios do calendário sociocultural local, como a festas religiosas em alusão a Santa Luzia, e realizados no entorno da comunidade, como as relacionadas às festas na localidade de Carmo do Maruanum ou como as que se seguem no mês de julho, época em que acontece o evento intitulado 'Macapá Verão'.

Quadro 3 - Santa Luzia do Maruanum: períodos anuais de lazer

\begin{tabular}{|l|}
\hline P: Qual o melhor período do ano quando se pensa lazer? \\
\hline E2: "É o mês de julho, que tem a festa do Carmo e a gente vai pra lá, dão o almoço, tem \\
brincadeira...”. \\
E3: "Em dezembro que tem a festa de santa Luzia". \\
E6"Julho. Que no Maruanum tem o Macapá verão... por causa do balneário aqui que é todo \\
final de semana e as festas também".
\end{tabular}

Fonte: Pesquisa de campo (2019).

De acordo com Pereira (2008), as festas e ritos de cunho religioso presentes nas manifestações culturais da maioria dos povos afrodescendentes do Amapá, acompanham o marabaixo e o batuque, sendo na comunidade de Santa Luzia do Maruanum, uma das características que se perpetuam e envolvem todos os moradores locais.

Dentre estes espaços, a comunidade possui um espaço físico destinado para realizações de 'festas dançantes', bingo, aniversários e preparo para festas religiosas, e alguns locais que resistem ao tempo e a memória da cultura local, como o centro comunitário e a própria igreja, símbolo de Santa Luzia. As festas articulam lazer, momentos de sociabilidade e manifestações identitárias, bem como estão ligadas a trabalho. 
DOI: 10.47694/issn.2674-7758.v2.i7.2021.162191

Figura 5 - Balneário da comunidade

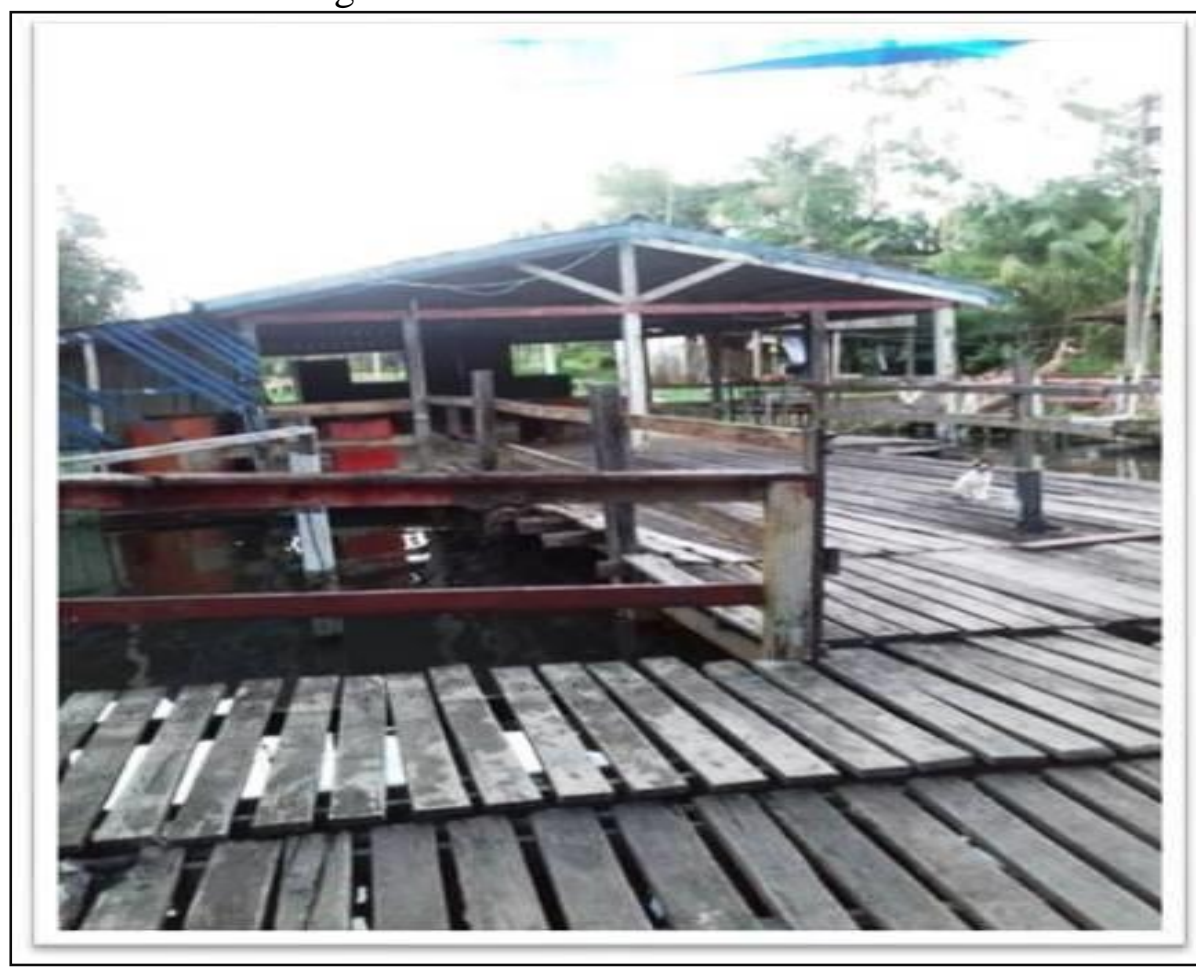

Fonte: Pesquisa de campo (2019).

Para Hall (1997) toda prática social se estabelece em condições e existência de

cultura, que sob os discursos da cultura constroem-se identidades sociais identificáveis ou assumíveis. Esses percursos de identificações se mostram complexos, dada a plasticidade das identidades, o que de acordo com Agier (2001), tornam necessárias as análises situacionais das culturas e identidades.

Figura 6 - Sede de eventos de Santa Luzia do Maruanum

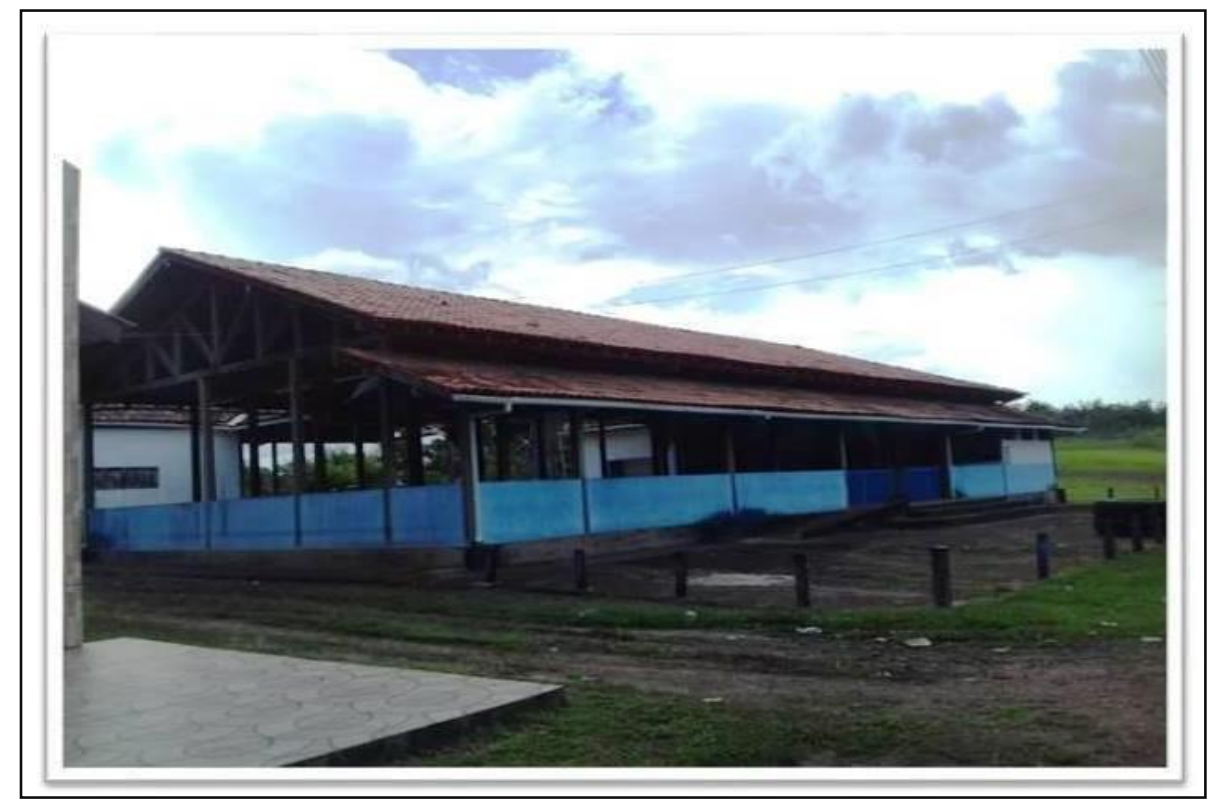

Fonte: Pesquisa de campo (2019).

Revista Escritas do Tempo - v. 3, n. 7, jan-abr/2021 - p. 162-191 
Com base na pergunta sobre quais as manifestações culturais da comunidade, aproximando as expressões de lazer à cultura, as respostas se concordavam em, marabaixo, festas dançantes, festas religiosas, quadrilha e bingo; além de serem consentidas com características não somente limitadas ao interior da localidade, mas sob a dimensão do distrito geral, o que reconhece todas as 'festas de santo' como partes componentes das percepções de manifestações culturais características.

Quadro 4 - Santa Luzia do Maruanum: manifestações culturais

\begin{tabular}{|l|}
\hline P: Quais as manifestações culturais da comunidade? \\
\hline E4: "Santa Luzia, o marabaixo e toda essa animação aí...".
\end{tabular}

Fonte: Pesquisa de campo (2019).

Em seguida, perguntamos o que estas manifestações da cultura representam para estes enquanto moradores e vivenciadores dessas expressões. As respostas condiziam com as percepções de identidade cultural autorreconhecida, em alusão a cultura tradicional e à memória social.

Quadro 5 - Santa Luzia do Maruanum: representatividade e cultura

\section{P: O que as manifestações da cultura da comunidade representam?}

E4: "Pra mim, pra te falar a verdade, desde quando me entendi já estava isso aí dos meus avôs, dos meus pais e aí nos tomos metido no meio e aí...".

E5: "Pra mim representa alegria. Que eu estou esquecendo de todo meu sacrifício e me lembrando só de alegria".

E9: "Importante. A gente aproveita bem".

Fonte: Pesquisa de campo (2019).

Tais inferências possibilitaram aberturas às percepções das dimensões sociais, que interagem com o subjetivo, tendo em vista que nas ampliações contemporâneas sobre os estudos de lazer e ócio, as aproximações (res)significadas se tornaram possíveis com base na admissão de uma estrutura complexa do social, contornado pela atividade influenciadora do trabalho, sob um modelo cultural urbano, moderno capitalista.

Considerando a importância de interpretar a cultura no seu sentido complexo e sob uma leitura crítica ao contemporâneo, Ortner (2007), contribui para acentuar a importância da produção cultural dos sujeitos, não somente posicionando o lugar dos 
sujeitos na base social, econômica, religiosa, mas recordando-os como subjetividades complexas, que não se esgotam nos limites analíticos de uma localização estrutural fixa - o que permite possibilidades reflexivas em resgate ao homem e suas performances culturais, imbricações diversas que podem se aproximar do que Cuche (2012) percebeu nas anunciações de representatividades políticas.

Por ser parte constituinte das significações subjetivas de lazer e ócio, a felicidade, como resultado das vivências de lazer (GOMES, 2004), ou como sensações resultantes dos benefícios das experiências de ócio (RHODEN, 2009), as questões que abordam a felicidade se fizeram necessárias para possíveis aprofundamentos das reflexões. Com base nisso, primeiramente, buscou-se compreender o que os moradores entrevistados entendiam por felicidade, considerando suas visões significativas, em seguida, se estes se sentiam felizes e no âmbito da comunidade, tendo em vista uma localização do contexto social.

Quadro 6 - Santa Luzia do Maruanum: definição de felicidade

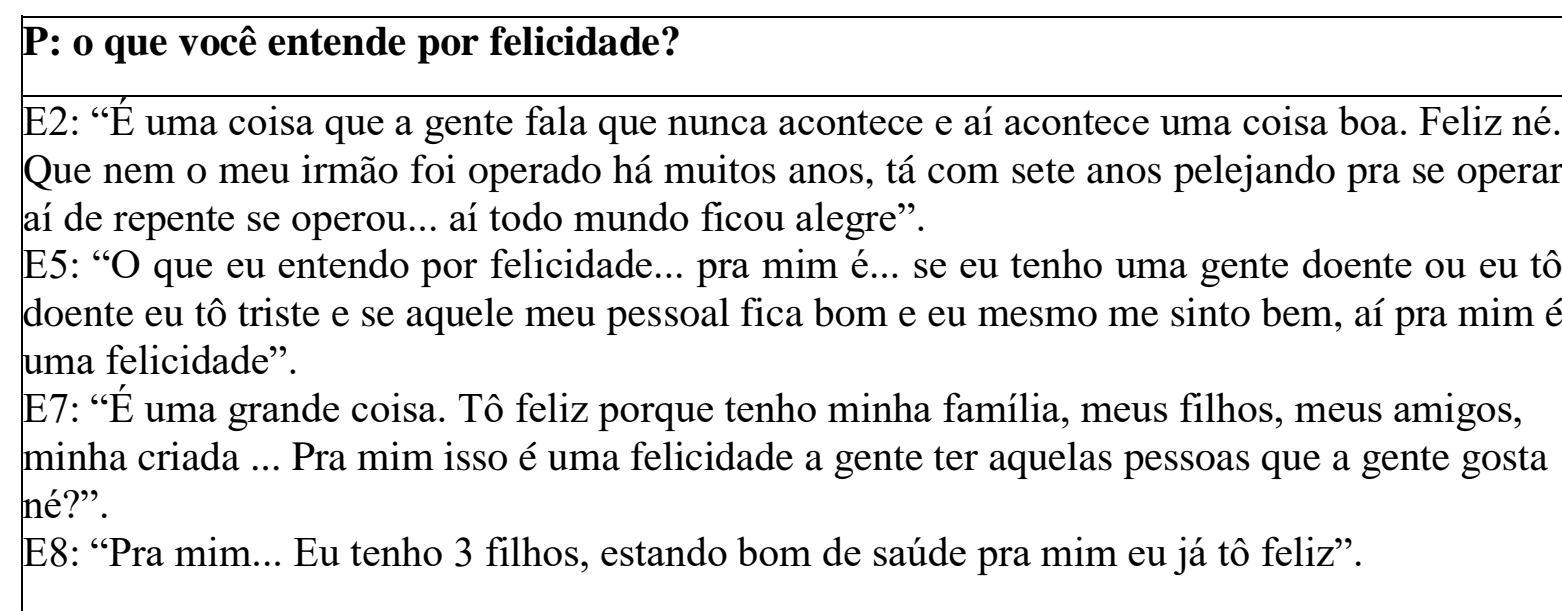

Fonte: Pesquisa de campo (2019).

A representação da felicidade, nesse sentido, se apresentou como resultado de um bem estar físico e destacando o sentido de coletividade, de estar perto de quem se gosta além de ser percebido pela vivência ao próprio contexto espacial da comunidade, interpretado como um agrado em estar ali morando e vivendo na relação com a natureza. 
Quadro 7 - Santa Luzia do Maruanum: percepções de felicidade

\begin{tabular}{l}
\hline P: Qual a sua percepção de felicidade? \\
\hline E3: “viver em paz com a natureza. Eu mesmo, preferia tá aqui dentro que em qualquer \\
outro lugar, porque pra 'mim' sair daqui pra viver em outro lugar...não consigo mais." E4: \\
"tem um terreno ali aonde nós vamos... Pra mim é uma felicidade quando a gente chega lá". \\
E10: "felicidade pra mim... É bom aqui pra viver, eu gosto daqui se fosse pra morar em \\
Macapá eu não ia não, ficava aqui mesmo".
\end{tabular}

Fonte: Pesquisa de campo (2019).

Notou-se que a felicidade ou expressões dessa, encontrou significados no âmbito de uma realização de prioridades que condicionam a sua existência ou como sentimentos resultantes de realizações pessoais e em comum, tais como a relação da felicidade facilitada ou resultante da ideia de qualidade de vida, tanto individual como da família e amigos, demonstrando assim, a preocupação com a saúde pessoal e coletiva.

Quando questionados se estes se consideravam felizes no âmbito da comunidade, dessa forma, todos responderam afirmativamente, certeza esta projetada pelo sentimento de pertencimento e de satisfação em residir na comunidade, impressões percebidas também, pelo ‘tom de orgulho' nas respostas.

Quadro 8 - Santa Luzia do Maruanum: comunidade e felicidade

\section{P: Se sente feliz em sua comunidade?}

E5: "Feliz! Feliz! Feliz!... Muito feliz!”.

Fonte: Pesquisa de campo (2019).

Quando questionados sobre a saída ou procura de lazer em outros lugares fora do âmbito da comunidade, as respostas confirmaram uma valorização de residirem e usufruírem do espaço da comunidade, o que demonstrou pouca procura de lazer fora, a não ser dentro dos entornos as demais comunidades vizinhas. Os demais afirmaram não sair da comunidade em busca de lazer ou afirmando sair poucas vezes.

Quadro 9 - Santa Luzia do Maruanum: buscas por lazer

\section{P: Sai da comunidade para outros lugares em busca de lazer?}

E6: "Outras comunidades que não é aqui na comunidade. A gente vai em Campina Grande..."

E7: "Difícil. Fico aqui mesmo".

Fonte: Pesquisa de campo (2019). 
Quanto às percepções de necessidades relativas ao lazer, a grande maioria não enxergava nenhuma necessidade. No entanto, a manutenção do balneário apresentou-se como uma necessidade, tendo em vista o desgaste causado pelo tempo. O balnário tem uma importância marcante dentro da comunidade, tendo em vista a utilização do espaço para lavagens de roupa, banhos, ponto de descida de crianças que realizam percurso para ir e chegar da escola na comunidade vizinha por meio das embarcações.

Quadro 10 - Santa Luzia do Maruanum: necessidades de lazer

\begin{tabular}{l} 
Quais as necessidades da comunidade em relação ao lazer? \\
\hline E5: "Não. Se falta a gente mesmo dá o jeito por aqui”. \\
E4: "Tá. Porque nosso balneário aqui, se você vai lá, tá precário. Nós que estamos \\
agradando...". \\
E7: "Sim. Aqui na nossa comunidade não tem quase nada, as pessoas que fazem o \\
lazer... \\
precisa de uma infraestrutura muito maior, um lugar adequado pra eles jogarem bola".
\end{tabular}

Fonte: Pesquisa de campo (2019).

\section{Considerações Finais}

Para compreender a estruturação e sentidos do tempo social da comunidade de Santa Luzia do Maruanum, recortamos etnograficamente as expressões de trabalho e lazer da comunidade. Desta forma, adotamos tradições teóricas e problematizações que aproximam as diferentes estruturações do tempo, o trabalho, o lazer, o ócio (como liberdade), pelo aspecto da subjetividade, da liberdade, da motivação e da felicidade resultante das experiências de trabalho e lazer.

O trabalho, como expressão do tempo, desdobra-se em diferentes atividades. Estas atividades todavia não são a forma com que se preenhe o tempo. Elas são o próprio tempo. O sentido de fazê-las, as atividades em si e o estado de espírito com que se as vive, são o tempo comunitário. O lazer como prática ou expressão que resultam sensações de alegria e prazer equivale-se às práticas culturais, como festas tradicionais e preparativos religiosos e como práticas de um lazer cuja finalidade é a convivência social, como um banho de rio ou de uma partida de futebol ou como ponto de encontros para conversas, entre o brincar das crianças, o lavar de roupas e o avistar de conhecidos que entrecruzam pelas embarcações, seja com destino às suas casas, que permanecem 
frequentemente abertas, sem nenhum receio de adentrarem estranhos.

Trabalho e felicidade não se separam, como no tempo social eurocêntrico, como testemunha o deslocamento animado de uma senhorinha que sobre manobras de uma canoa, atravessava perto de nós em direção a sua busca para o achado do material mais adequado da produção artesanal das louças, a qual, conforme relatos de sua filha, presente a observar a mãe que partia e concedia a benção solicitada, que tal empreitada se fazia constante.

O tempo do trabalho é importante e ocupa um dos lugares centrais na vida comunitária, todavia, não é um tempo que aliena os moradores de sua subjetividade. A autodeterminação em relação ao tempo de trabalho e lazer supera qualquer pressão irracional do tempo de trabalho. Isto se expressa na maneira como os moradores criam suas alternativas de vivências temporais e de caráter de obrigatoriedades pessoais, onde se percebe uma maior atitude de autodeterminação de realizações, como por exemplo, deixar para mais tarde uma tarefa necessária de finalização para poder ir ao rio com a família no intuito de conversar e se divertir.

O tempo social comunitário é feito por um tempo de trabalho, um tempo familiar, um tempo religioso, e um tempo de lazer cotidiano e festivo extracotidiano. O tempo social comunitário é feito também deste 'tempo escolhido', desta autodeterminação, desta autonomia relativa para decisão sobre o cotidiano.

\section{Referências}

AGIER, M. Distúrbios identitários em tempos de globalização. Mana, n. 7, v. 2, p. 7- 33. 2001.

ALMEIDA, A. W. B. Terra de quilombo, terras indígenas, "babaçuais livre", "castanhais do povo", faixinais e fundos de pasto: terras tradicionalmente ocupadas. 2. ed, Manaus: PGSCA/UFAM, 2008.

AQUINO, C. A. B. O tempo como substancialidade do trabalho: o tempo industrial e o tempo do trabalho. Revista do Labor, Fortaleza, v. 01, n. 01, p. 01-14. 2008.

AQUINO, C. A. B.; MARTINS, J. C. Ócio, lazer e tempo livre na sociedade do consumo e do trabalho. Fortaleza: Rev. Mal-Estar e Subjetividade, v. 07, n. 02, p. 479-500, set.2007.

AQUINO, C. A. B.; MARTINS, J. C. Ócio, lazer e tempo livre na sociedade do consumo e do trabalho. Rev. Mal-Estar e Subjetividade, v. 7, n. 2, p. 479-500, set. 2007.

ARRUTI, J.M. A. A emergência dos "remanescentes": notas para o diálogo entre indígenas e quilombolas. Mana, Rio de Janeiro, v. 03, n. 02, p. 07-38, out. 1997.

BALLESTRIN, L. América Latina e o giro decolonial. Revista Brasileira de Ciência Política, Brasília, n. 11. p. 89-117, mai./ago., 2013.

BOAS, F. Antropologia cultural. Trad. Celso de Castro. 6. ed. Rio de Janeiro: Jorge Zahar Ed., 2010. 
BRANDÃO, C. R.; BORGES, M. C. 2014. O lugar da vida: comunidade e comunidade tradicional. Rev. Campo-Território, v. 09, n. 18, p. 01-23. 2014.

BRANDÃO, C. R.; LEAL, A. Comunidade tradicional: conviver, criar, resistir. Revista da ANPEGE, v. 08, n. 09, p. 73-91, jan./jun. 2012.

BRASIL. Constituição Federal (1988). Constituição da República Federativa do Brasil, edição 35. Brasília, DF: Edições Câmaras, 2012.

CABEZA, M, C. O ócio autotélico. In: MARTINS, J. C. (Org.). Revista do Cento de Pesquisa e Formação, n. 02, p. 10-29. 2016.

CANDAU, V. M. (Org.). Educação intercultural e cotidiano escolar. Rio de Janeiro: 7 Leras, 2006.

COSTA, A. M. Lazer e sociabilidade: usos e sentidos. Coleção trilhas amazônicas. Belém: Açaí, 2009.

COSTA, C. S.; CUSTÓDIO, E. S. Religião, Cultura e Políticas públicas no Amapá: religiosidade, cerâmica e encantaria na tradição das louceiras do Maruanum. Rev. Eletrônica Correlativo, v. 16, n. 02, dez. 2017.

COSTA, S. Desprovincializando a sociologia: a contribuição pós-colonial. Rev. Bras. Cienc. Soc., São Paulo, v. 21, n. 60, p. 117-134, 2006.

CPISP. Comissão Pró Índio de São Paulo. Santa Luzia do Maruanum I. 2019. Acesso em: 10 out. 2019.

CUCHE, Denys. A noção de cultura nas ciências sociais. Bauru: EDUSC, 2012.

DIEGUES, A. C. S. O mito moderno da natureza intocada. São Paulo: Editora Hucitec, 1996.

DIEGUES; A. C. S.; ARRUDA; R. S.V. (Org.). Saberes tradicionais e biodiversidade no Brasil. Brasília: Ministério do Meio Ambiente; São Paulo: USP, 2001.

DUMAZEDIER, J. Sociologia Empírica do lazer. São Paulo: Perspectiva, 1979.

ELIAS, N. Sobre o tempo. Trad. Vera Ribeiro. Rio de Janeiro: Jorge Zahar Editora, 1998. FERREIRA, F.C. 'Desde que me entendi': tecendo saberes e fazeres relativo à louça da comunidade quilombola do Maruanum, Macapá/AP. Dissertação (Mestrado em Antropologia) - Universidade Federal do Pará, 2016.

FILHO, A. C. Quilombos e povos tradicionais. 2011. Disponível em: https://bit.ly/2HwDU4M. Acesso em: 19 jun. 2019.

FREITAS, H.; MUNIZ, R. J. Uma proposta de plataforma para influência estratégica. Rio Grande do Sul: UFGS, 2008.

GEERTZ, C. A Interpretação das Culturas. Trad. Fanny Wrobel. Rio de Janeiro: Zahar Editores, 1978.

GOMES, C. L. Lazer: Concepções. In: GOMES, C. L. (Org.). Dicionário Crítico do Lazer. Belo Horizonte: Autêntica Editora, 2004. p. 119-126.

GOMES, C. L. Lazer: necessidade humana e dimensão da cultura. Revista Brasileira de Estudos do Lazer, Belo Horizonte, v. 01, n. 01, p. 03-20, jan./abr. 2014. Disponível em: https://bit.ly/329MXR0. Acesso em: 01 jul. 2019.

GOMES, C. L. Lazer: ocorrência histórica. In: GOMES, C. L. (Org.). Dicionário Crítico do Lazer. Belo Horizonte: Autêntica Editora, 2004. p. 133-141.

GOMES, C. L. O lazer como campo mobilizador de experiências interculturais e sua contribuição para uma construção transformadora. In: DALBEN, Â.; DINIZ, J.; LEAL, L.; SANTOS, L. (Orgs.). Convergências e tensões no campo da formação e do trabalho docente: Currículo, Ensino de Educação Física, Ensino de Geografia. Belo Horizonte: Autêntica Editora, 2010. p. 284-310.

GONÇALVES, A. L. História \& Gênero. Belo Horizonte: Autêntica, 2006, p. 48-49.

HALBWACHS, M. A memória coletiva. São Paulo: Ed. Centauro, 2004.

HALL, S. A centralidade da cultura: notas sobre as revoluções culturais do nosso tempo.

Educação \& Realidade, Porto Alegre, v. 22, n. 02, p. 15-46, jul./dez. 1997. 
HALL, S. A questão da identidade cultural: Textos didáticos. São Paulo: IFHC/Unicamp, 1998.

HALL, S. Quem precisa da identidade? In: SILVA, T. (Org.). Identidade e diferença: a perspectiva dos estudos culturais. Petrópolis: Vozes, 2007.

IAPARRÁ, D. S.; LOMBA, R. M. Santa Luzia do Maruanum I: uma análise do quilombo em face do processo de reconhecimento e delimitação do território. In: VII Congresso Brasileiro de Geógrafos. 10-16 de ago. de 2014, Vitória/ ES. Anais..., 2014. p. 01-12. Acesso em: 21 jul. 2019.

LITTLE, P. E. Territórios Sociais e Povos Tradicionais no Brasil: por uma antropologia da territorialidade. Anuário antropológico 2002-2003. Rio de Janeiro: Tempo Brasileiro, 2004. p. 251-290. Disponível em: https://bit.ly/2nLezKm. Acesso em: 19 jul. 2019.

MACIEL, M. G.; SARAIVA, L. A. S.; MARTINS, J. C. O. Semelhanças e especificidades entre os estudos do ócio e os estudos do lazer. Rev. Subj., Fortaleza, v. 18, n. 02, p. 13- 25, ago. 2018. Disponível em https://bit.ly/2NHTwqe. Acesso em: 14 ago. 2019.

MARCELLINO, N. C. Estudos do lazer: uma introdução. Campinas: Autores Associados, 1996.

MARCELLINO, N. C. Lazer e humanização. Campinas: Papirus, 1983.

MARCELLINO; N. C.; PUKE, N. O lazer existencial: uma possibilidade de resposta para o absurdo. Licere, Belo Horizonte/MG, v. 16, n. 03, p. 01-31. 2013.

MARTINS, J. C. O. Investigações sobre o ócio. Unifor Notícias, n. 260. 2017. Acesso: 18 jul. 2019.

MARTINS, J. C. O. Sentidos e possibilidade subjetivas no tempo livre. Licere. Belo Horizonte, v. 11, n. 02, ago. 2008.

MARTINS, J. C. O.; AQUINO, C. A. B.; SABOIA, I. B.; PINHEIRO, A. A. G. De Kairós a Kronos: metamorfoses do trabalho na linha do tempo. Cadernos de Psicologia Social do Trabalho, v. 15, p. 219-229. 2012.

MÉSZAROS, I. Para além do capital: rumo a uma teoria da transição. Trad. Paulo Cezar Castanheira e Sérgio Lessa. São Paulo: Editora Boitempo, 2002.

MIGNOLO, W. Histórias locais/projetos globais: colonialidade, saberes subalternos e pensamento limiar. Trad. Solange Ribeiro de Oliveira. Belo Horizonte, Ed. UFMG, 2003. MONLEVADE, A. P. B.; CAETANO, E. Trabalho e produção associada em comunidades tradicionais: experiências de existências e resistências. Germinal Marxismo e Educação em debates. Salvador, v. 09, p. 220-229, dez., 2017.

MONLEVADE, A. P. B.; CAETANO, E. Trabalho e produção associada em comunidades tradicionais: experiências de existências e resistências. Germinal Marxismo e Educação em Debates. Salvador, v. 9, p. 220-229, dez. 2017.

MONTEAGUDO, M. J.; CUENCA, J.; BAYÓN, F.; KLEIBER, D. Ócio ao longo da vida: as potencialidades dos itinerários de ócio para a promoção do desenvolvimento humano. Trad. Andrei Manoliu e Maria Eliana Ortiz. Revista Lusófona de Estudos Culturais, v. 01, n. 02, p 155-172, dez. 2013.

Oliva-AUguSto, M. H. Tempo, indivíduo e vida social. Ciência e Cultura, São Paulo, v. 54, n. 2, p. 30-33, out. 2002. Disponível em: https://bit.ly/2MLAL5p. Acesso: 28 fev. 2019.

ORTNER, S. B. Subjetividade e crítica cultural. Horiz. antropol., Porto Alegre, v. 13, n. 28, p. 375-405, dez. 2007.

PACKER, L. A. Biodiversidade como bem comum: direito dos agricultores e agricultoras, povos e comunidades tradicionais. Curitiba: Terra de Direitos, 2012.

PEREIRA, B. E.; DIEGUES, A. C. S. Conhecimento de populações tradicionais como possibilidade de conservação da natureza: uma reflexão sobre a perspectiva da etnoconservação. Desenvolvimento e Meio Ambiente, n. 22, p 35-50, jul./dez. 2010. 
PEREIRA, D. L. O candomblé no Amapá: história, memória, hibridização e hibridismo cultural. Dissertação (Mestrado em História Social da Amazônia) — Universidade Federal do Pará - UFPA, Belém. 2008.

POUTIGNAT, P.; STREIFF-FERNART, J. Teoria da etnicidade: seguido de grupos étnicos e suas fronteiras de Frederik Barth. Trad. Elcio Fernandes. São Paulo: Editora da UNESP, 1998.

REIS, J. Sobre o tempo. Revista Filosófica de Coimbra. n. 9. Portugal. 1996. p. 143-203. RHODEN, I. O ócio como experiência subjetiva: contribuições da psicologia do ócio. Fortaleza: Revista Mal-Estar e Subjetividade, vol. 09, n. 04, p. 1233-1250, dez. 2009. Acesso em: 28 jan. 2016.

ROCHA, G. F. A territorialidade quilombola ressignificando o território brasileiro: uma analise interdisciplinar. Revista do CAAP, n. 02, p. 233-253, jul./dez. 2009. Acesso em: 24 jul. 2019.

SANTOS, B. S. Um discurso sobre as ciências. 15. ed. Porto: Afrontamento, 2007.

SANTOS, B. S.; MENESES, M. P. (Orgs.). Epistemologias do sul. São Paulo: Cortez, 2010.

SILVA, A. T. R. A conservação da biodiversidade entre os saberes da tradição e a ciência. Rev. Estudos Avançados, v. 29, n. 83, São Paulo, jan./abr. 2015.

SILVANI, J. M. $O$ valor da cultura: um estudo de caso sobre a inserção da louça do Maruanum/AP no mercado e sua relação com a preservação do patrimônio cultural. Dissertação (Mestrado em Preservação do Patrimônio Histórico Cultural) - Instituto do Patrimônio Histórico e Artístico Nacional - IPHAN. Rio de Janeiro, 2012. SOUZA SILVA, D. J. Entre passado e futuro: memória social do Quilombo do Rosa, Macapá, Amapá. Geo UERJ, Rio de Janeiro, n. 37, p.1-17, 2020.

VIEIRA, J. G. S. Metodologia de pesquisa científica na prática. Curitiba: Editora Fael, 2010.

WEISSMANN, L. Multiculturalidade, transculturalidade, interculturalidade. Constr. psicopedag., São Paulo, v. 26, n. 27, p. 21-36, 2018.

Artigo recebido em 30 de janeiro de 2021. Aprovado em 20 de abril de 2021. 